\title{
Escola, professor e autoridade
}

\author{
Elizabeth Tunes, (DD I, Zoia Prestes (D) II (Organizadoras) \\ ${ }^{I}$ Universidade de Brasília e Centro Universitário de Brasília, Brasília, DF, Brasil

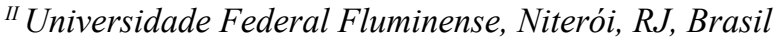

A Educação está em crise. Trata-se de mais uma das manifestações da crise de autoridade iniciada há séculos com o advento da modernidade. Embora alguém possa pensar que essa crise seja restrita à escola, isso não é verdade. Muito tempo se passou desde que a família começou a ver-se desautorizada na sua função educativa. Foram muitos os programas governamentais que visavam retirar da família a sua responsabilidade pela educação inicial das crianças, especialmente as mais pobres. Quem não se lembra da ideia de educação compensatória, claramente voltada para a suposta superação da incompetência da família para educar seus filhos? Quem não sabe que, nos dias atuais, a criança é obrigada a ingressar na escola logo após completar quatro anos? Por quê? Só há uma resposta possível: porque a família não tem competência para propiciar a educação necessária às crianças acima de quatro anos. Ao invés de ser tratada como aliada da escola, a família se transformou em problema; educar resume-se, hoje, à transmissão de conteúdos apartados da vida real, portanto, alienados do que crianças e adolescentes vivenciam diariamente.

Makarenko (1980, p. 257) diz:

O pai e a mãe foram incumbidos pela sociedade da educação do futuro cidadão do país, eles respondem por isso diante da sociedade; nisso se fundamenta o poder dos pais e de sua autoridade diante das crianças. Porém, não se pode ficar o tempo todo justificando o poder dos pais e recorrendo ao que lhe foi delegado pela sociedade. A educação da criança começa desde a idade em que é impossível apresentar qualquer comprovação lógica de normas sociais, entretanto, educar sem autoridade é impossível.

Historicamente, a escola tem sido grande aliada no processo de usurpar da família o seu poder de educar os filhos: o poder de educar transferiu-se da família à instituição escolar. Todavia, eis que a escola também se torna alvo de tal desautorização. O professor, figura central no processo educativo na escola, vê-se completamente desautorizado para o cumprimento de sua função de educador. Ele é a bola da vez. E, para resolver os problemas da educação brasileira, entra em campo a militarização dos espaços escolares que pretende impor disciplina e ordem, delegando a policiais a tarefa de educar crianças e adolescentes. Alegando-se a presença cada vez mais frequente do fenômeno da violência, principalmente em favelas e comunidades, argumenta-se que, "por meio da formação com a disciplina e as normas do regime militar, as crianças e adolescentes poderiam crescer com mais noção de limites e não entrariam para a criminalidade" (RIO DE JANEIRO, PL 3.188/2017).

A crise da educação parece ser, assim, a crise da autoridade, e um dos mais fortes indícios disso encontra-se na frequente e marcante violência que ocorre na escola, na maior parte das vezes envolvendo alunos e professores. Afinal, onde não há autoridade impera a violência, a força. Por isso, não temos dúvida de que a militarização das escolas, em curso em diferentes estados do Brasil, está associada à perda da autoridade do professor e ao emprego da força numa perspectiva de "disciplinarização" dos alunos para que obedeçam a uma determinada "ordem", e não para tirá-los do crime e muito menos para que se tornem pessoas reflexivas e questionadoras.

As duas questões - a perda de autoridade do professor e a violência escolar - são examinadas nos dois primeiros artigos deste dossiê. Um é assinado por Elizabeth Tunes e Zoia Prestes e o outro, por Vladimir Sobkin e A. S. Fomitchenko. O texto de Sobkin e Fomitchenko demonstra que o fenômeno da violência escolar está presente em todo o mundo ocidental e parece ter, de algum modo, como não poderia deixar de ser, a própria anuência do professor, na medida exata do modo como se desresponsabiliza pelo processo educativo, conforme também é apontado no artigo de Ingrid Lilian Fuhr, que examina o ofício docente e em que medida o professor abdica de sua responsabilidade social.

Somos todos chamados a responder a esse momento grave e crítico por que passa a educação. Seja como psicólogos profissionais, seja como pesquisadores e professores encarregados da formação de psicólogos e professores, é nosso dever refletir e colaborar para o enfrentamento dessa crise. Oleg Kravtsov examina como estudantes percebem a autoridade do professor, buscando compreender o papel da maturidade nessa percepção, especialmente em adolescentes com comportamento divergente. Do mesmo modo, os autores Sheila F. Machado, Sérgio H. da Silva Alves e Patrícia F. Caetano procuram examinar condições psicológicas específicas do adolescente que possam estar ligadas ao desenvolvimento de suas habilidades sociais. Num sentido semelhante, tratando, contudo, do professor, Viviane P. Lourenço, Amália R. Pérez-Nebra, Aristides I. Ferreira e Marina Kohlsdorf apresentam um estudo que contribui para se compreender a relação entre bem-estar e produtividade de docentes.

Finalmente, os três últimos artigos apresentam programas de ações realizadas que se configuram como possibilidades de enfrentamento da crise. O texto de Marta Chaves demonstra a necessidade de formar o educador intelectual, tendo por base a afirmação de novos princípios fundantes para reger a educação; o de Márcia Mara Ramos procura

\footnotetext{
^Endereço para correspondência: Universidade de Brasília. Campus Asa Norte - ASA NORTE. CEP: 70000-000 - Brasília, DF - Brasil. E-mails: bethtunes@gmail. com,zoiaprestes@yahoo.com.br.
} 
mostrar como as alternativas de resistência coletivamente construídas na práxis social do Movimento dos Trabalhadores Rurais Sem Terra (MST) traduzem-se em novas formas de organização da educação; e, por seu turno, o de E. L. Gorlova apresenta ao professor fundamentos alternativos e novas possibilidades para reorientar seu modo de ensinar.

Defendemos uma educação que tenha como perspectiva o futuro; afinal, crianças e adolescentes viverão no futuro, e essa perspectiva do futuro deve envolver o trabalho de quem assume a responsabilidade de educar e ensinar.

O mais importante e que nos acostumamos a valorizar no ser humano é sua força e sua beleza, que podem ser definidas nele exclusivamente pelo tipo de relação que estabelece com uma perspectiva. O ser humano que orienta seu comportamento por uma perspectiva mais próxima é uma pessoa fraca. Caso ele se satisfaça apenas com sua própria perspectiva, mesmo que seja de longo prazo, pode até parecer forte, porém não provoca em nós um sentimento de beleza em relação a sua personalidade e a seu real valor. Quanto mais amplo for o coletivo, com perspectivas que são também perspectivas individuais, mais bonita e elevada é a pessoa (MAKARENKO, 1980, p. 247).

Esperamos que a leitura dos textos aqui apresentados enseje novas análises e reflexões para que, juntos, possamos todos caminhar em direção à superação correta, justa e promissora da crise por que passamos.

\section{Referências}

RIO DE JANEIRO. ASSEMBLÉIA LEGISLATIVA DO ESTADO DO RIO DE JANEIRO. Projeto de Lei $n^{\circ}$ 3.188/2017. O Poder Executivo poderá transformar escola da rede estadual de educação em colégio militar, no âmbito do Estado do Rio de Janeiro. Disponível em: encurtador.com.br/jDYZ3. Acesso em: 20 jun. 2020.

MAKARENKO, Anton Semionovitch. Metodika organizatsii vospitatelnogo protsessa [Metodologia de organização do processo educativo]. In: GREBENSCHIKOVA, Elizaveta Anatolievna et al. Istoria sovetskoi dochkolnoi pedagoguiki. Rhrestomatia. [História da educação pré-escolas soviética. Coletânea]. Moskva: Prosveschenie, 1980. 